\title{
Retinoic Acid Receptor-Related Orphan Receptors: Critical Roles in Tumorigenesis
}

\begin{abstract}
Jinshuo Fan ${ }^{1 \dagger}$, Zhilei Lv't, Guanghai Yang ${ }^{2 \dagger}$, Ting ting Liao', Juanjuan $X u^{1}$, Feng $W u^{1}, Q i$ Huang ${ }^{1}$, Mengfei Guo ${ }^{1}$, Guorong Hu', Mei Zhou', Limin Duan', Shuqing Liu' and Yang Jin ${ }^{1 *}$

${ }^{1}$ Key Laboratory of Respiratory Diseases of the Ministry of Health, Department of Respiratory and Critical Care Medicine, Union Hospital, Tongji Medical College, Huazhong University of Science and Technology, Wuhan, China, ${ }^{2}$ Department of Thoracic Surgery, Union Hospital, Tongji Medical College, Huazhong University of Science and Technology, Wuhan, China
\end{abstract}

Retinoic acid receptor-related orphan receptors (RORs) include ROR $\alpha$ (NR1F1), ROR $\beta$ (NR1F2), and ROR $\gamma$ (NR1F3). These receptors are reported to activate transcription through ligand-dependent interactions with co-regulators and are involved in the development of secondary lymphoid tissues, autoimmune diseases, inflammatory diseases, the circadian rhythm, and metabolism homeostasis. Researches on RORs contributing to cancer-related processes have been growing, and they provide evidence that RORs are likely to be considered as potential therapeutic targets in many cancers. ROR $\alpha$ has been identified as a potential therapeutic target for breast cancer and has been investigated in melanoma, colorectal colon cancer, and gastric cancer. ROR $\beta$ is mainly expressed in the central nervous system, but it has also been studied in pharyngeal cancer, uterine leiomyosarcoma, and colorectal cancer, in addition to neuroblastoma, and recent studies suggest that ROR $\gamma$ is involved in various cancers, including lymphoma, melanoma, and lung cancer. Some studies found ROR $\gamma$ to be upregulated in cancer tissues compared with normal tissues, while others indicated the opposite results. With respect to the mechanisms of RORs in cancer, previous studies on the regulatory mechanisms of RORs in cancer were mostly focused on immune cells and cytokines, but lately there have been investigations concentrating on RORs themselves. Thus, this review summarizes reports on the regulation of RORs in cancer and highlights potential therapeutic targets in cancer.

Keywords: retinoic acid receptor-related orphan receptors, $\mathrm{ROR} \alpha, \mathrm{ROR} \beta, \mathrm{ROR} \gamma$, cancer

\section{INTRODUCTION}

Cancer incidence and mortality rates are increasing worldwide with the growing and aging of the population, as well as risk factors such as outdoor pollution, tobacco smoke, and physical inactivity (1). Due to early detection and advanced treatments, cancer survival rates continue to grow, although a better understanding of carcinogenesis may lead to more effective treatment options for cancer.

The nuclear receptors (NRs) have been demonstrated to play essential roles in cancer-related progresses and to be potential therapeutic targets for many malignancies (2-5). The retinoic acid receptor-related orphan receptors (RORs) are a subfamily of the thyroid hormone receptor, which is a subfamily of the NRs and belonging to the orphan NR family (6). The ROR subfamily contains three members: ROR $\alpha$ (NR1F1), ROR $\beta$ (NR1F2), and ROR $\gamma$ (NR1F3). 
Members of the RORs are typically regarded as noteworthy in inflammation, autoimmune diseases, metabolism disorders, circadian rhythms, development of neuron cells, and immune cell differentiation. Although RORs share some common sequences, the three RORs present a wide assortment of features. $\operatorname{ROR} \alpha$ and ROR $\gamma$ are important regulators of the immune system. For instance, the development and differentiation of Th17 cells are dependent on these factors (7-9). Moreover, studies show that ROR $\gamma$ is expressed in lymphoid tissue inducer cells, innate lymphoid cells, invariant natural killer T cells, and $\gamma \delta \mathrm{T}$ cells, which contribute to inflammation and autoimmune disease (10).

$\operatorname{ROR} \alpha, \operatorname{ROR} \beta$, and $\operatorname{ROR} \gamma$ are all involved in the modulation of circadian rhythms. ROR $\alpha$ functions as a positive regulator of the circadian modulator Bmall through binding to RORresponsive elements (ROREs) $(11,12)$. ROR $\beta$ mRNA expression levels were found to oscillate with true circadian rhythms, peaking at night-time (13), and modulation of circadian rhythms was disrupted in ROR $\beta$-deficient mice (14). Recent studies have proposed that $\operatorname{ROR} \gamma 1$, but not $\operatorname{ROR} \alpha$, is periodically expressed, and ROR $\gamma$ regulates several clock genes, such as Cry1, Bmal1, and Npas2, directly in a Zeitgeber time-dependent manner through these ROREs $(15,16)$.

Accumulating evidence shows that $\operatorname{ROR} \alpha$ and $\operatorname{ROR} \gamma$ are involved in lipid/glucose metabolism, insulin sensitivity, and cardiometabolic control (17). A report showed that ROR $\alpha$ could repress the transcriptional activity of PPAR $\gamma$, leading to dysregulation of hepatic lipid metabolism (18). Recently, studies have shown that metabolic disorders affected by circadian rhythms might be attributed to ROR $\alpha$ and ROR $\gamma$, partly because of their modulation in both circadian and metabolic diseases. Moreover, earlier studies suggested that $\operatorname{ROR} \alpha$ was directly involved in melatonin-mediated anti-fibrotic processes (19) and beneficial manipulation in diabetic cardiomyopathy (20).

The expression sites and producing cells of RORs are also distinct from each other, consistent with their functions in the various diseases mentioned above. $\operatorname{ROR} \alpha$ and $\operatorname{ROR} \gamma$ are expressed in all skin cell types, including epidermal keratinocytes, melanocytes, dermal fibroblasts, and several established lines of malignant melanomas. The expression levels of $\mathrm{ROR} \alpha / \gamma$ are dependent on the skin cell type and can be regulated by hydroxy derivatives of vitamin D3 $(5,21-24)$. Vitamin D3 formation is regulated by UVB (25); vitamin D3 metabolites are inverse agonists for $\mathrm{ROR} \alpha / \gamma$; therefore, $\mathrm{ROR} \alpha$ and ROR $\gamma$ expression level could be regulated by UVB (5).

Other expression sites of $\mathrm{ROR} \alpha$ include the liver, skin, pancreas, brain, adipose tissue, islet cells, and the pineal gland. In addition to its expression and modulation in melanoma described above, $\mathrm{ROR} \alpha$ has been researched in breast cancer (BC) (26), melanoma (5), hepatocellular carcinoma (HCC) (27), and colon cancer (28). ROR $\beta$ is mainly expressed in the brain and pineal gland (29). $\operatorname{ROR} \beta$ is upregulated or downregulated in cancers such as primary leiomyosarcoma of the uterus (30), a pharyngeal cancer cell line (31), and colorectal cancer (28). ROR $\gamma$ is expressed in the thymus and lymphoid organs, and ROR $\gamma$ production in cancer cells is detected in lung cancer (4), lymphoma (32), melanoma (5), and $\mathrm{BC}(33)$.
The RORs have been widely investigated in cancer and have shown varying influences in cancer-related processes, these differences may be due to their structures and their tissue-specific expression. Some studies suggest that ROR $\alpha$ is a tumor suppressor and a potential therapeutic target for $\mathrm{BC}$; and based on the limited researches on $\operatorname{ROR} \beta$ in cancer, $\operatorname{ROR} \beta$ might be a tumor suppressor as well. Others have proposed that activating ROR $\gamma$ may exert antitumor immunity (34), while ROR $\gamma$ is considered as protumor candidates in prostate cancer and lung cancer $(4,35)$. In this review, we summarize and discuss the structures of RORs and their roles in cancer-related processes, highlighting the potential therapeutic targets for cancer treatment.

\section{STRUCTURE AND LIGANDS OF RORS}

The three ROR family members contain sequences similar to the retinoic acid receptor, with certain differences. The three ROR family members contain sequences similar to the retinoic acid receptor, but in minor details, the structures of each are distinct (36). The ROR $\alpha$ gene maps to human chromosome $15 \mathrm{q} 22.2$, covering a large genomic region of $730 \mathrm{~kb}$ and generating four human $\mathrm{ROR} \alpha$ isoforms: $\mathrm{ROR} \alpha 1-\mathrm{ROR} \alpha 4$, while only $\mathrm{ROR} \alpha 1$ and ROR $\alpha 4$ are found in mice (17). The ROR $\beta$ and ROR $\gamma$ genes map to human q21.13 and 1q21.3, covering 188 and $24 \mathrm{~kb}$, respectively. ROR $\beta$ and ROR $\gamma$ each generate two isoforms: ROR $\beta 1 /$ ROR $\beta 2$ and ROR $\gamma 1 / R O R \gamma 2$ (RORC2 in human and ROR $\gamma t$ in mice). The isoforms of RORs differ in their amino terminals due to alternative exon splicing and promoter usage and their distinct expression and function in different tissues. However, if cells co-express RORs, the co-expressed RORs may overlap in several functions.

Receptor-related orphan receptor genes encode proteins of similar amino sequences ranging from 459 to 556 amino acids according to the different isoforms, and they all consist of four domains. These domains include an N-terminal domain, a highly conserved DNA-binding domain, a ligand-binding domain (LBD), and a hinge between the domains. Transcription is regulated by binding to RORE as a monomer (36).

No cognate ligands of RORs had been identified until crystallography studies on the LBD of $\mathrm{ROR} \alpha$ indicated that cholesterol and cholesterol sulfate function as natural ligands (37). Several retinoids, including all-trans retinoic acid and the synthetic retinoid ALRT 1550 (ALRT), have been identified to bind ROR $\beta$, reversibly and with high affinity (38). Thus, the retinoids have been identified as ligands of $\operatorname{ROR} \beta$, although their specific regulation is not clearly understood. ROR $\gamma$ has been found to be co-expressed with $\operatorname{ROR} \alpha$, and the ligands of $\operatorname{ROR} \alpha$ and ROR $\gamma$ have been reported as sterols or their derivatives and secosteroids $(5,6)$. Endogenously produced novel D3 hydroxy derivatives can act as both "biased" agonists of the vitamin D receptor and inverse agonists of $\mathrm{ROR} \alpha / \gamma(22)$, and hydroxylumisterols can act as ligands of ROR $\alpha$ and ROR $\gamma$ (39). Melatonin was once considered a ligand for $\operatorname{ROR} \alpha(40,41)$. However, contrasting reports showed that melatonin was not a natural ligand for $\operatorname{ROR} \alpha$ because melatonin could not activate $\operatorname{ROR} \alpha$ directly $(42,43)$. The docking scores calculated from molecular modeling of interactions between melatonin 
and its metabolites with $\operatorname{ROR} \alpha$ and $\operatorname{ROR} \gamma$ predicted weak binding affinities (5), and the structures of melatonin and its metabolites were not similar to the sterols that were identified as natural ligands (37).

Except for the natural ligands of RORs mentioned above, there are also some synthetic ROR $\gamma$ ligands with therapeutic potential identified in literatures $(6,44)$. For instance, the inverse agonists of ROR $\alpha$ and $\operatorname{ROR} \gamma, \mathrm{SR} 2211$ has been reported to inhibit the expression of IL-17A and cell viability in lung cancer (4) and suppress inflammation in a collagen-induced arthritis mouse model (45). And ROR $\alpha$ and ROR $\gamma$ agonist SR1078 can induce cancer cell apoptosis and p53 stability (46). Inverse agonists or agonists like these two are promising therapeutic reagents for the diseases that RORs involved in, but there are still lack of studies to investigate their treatment potentials in cancer.

\section{CANCER RELEVANCE}

As illustrated above, RORs have been implicated in autoimmune or immune-mediated disease, the circadian rhythm, and metabolic disorders. RORs are also important regulators in various cancers due to their pivotal roles in immunity, the circadian rhythm, and metabolic homeostasis, which contribute to tumor progression.

$\operatorname{ROR} \alpha$ has been found to be downregulated in keratinocytederived skin cancer (47) and is expressed in prostate cancer cells (48), melanoma cell lines $(5,49)$, and BC (50) (Table 1). Decreased expression of $\mathrm{ROR} \alpha$ is positively related with melanoma progression and shorter disease-free and overall survival $(23,24) . \operatorname{ROR} \alpha$ is also involved in inhibiting cell proliferation as a tumor suppressor (51). In human hepatoma cells, $\mathrm{ROR} \alpha$ was found to be upregulated after hypoxia induction (52), while $\mathrm{ROR} \alpha$ expression was lower in tumor tissues than in adjacent tumor tissues. It was also determined to be involved in the reprogramming of glucose metabolism and inhibiting hepatoma growth both in vitro and in a xenograft model in vivo (53). However, in one report, the production of ROR $\alpha$ mRNA in colorectal cancer patients was unchanged (54), while ROR $\alpha$ phosphorylation was found reduced and might be involved in colon cancer progression (55). In another report about $\mathrm{BC}, \mathrm{ROR} \alpha$ was found to be downregulated, and low expression of ROR $\alpha$ mRNA was associated with a poor prognosis (26). ROR $\alpha$ is commonly considered a repressor (Figure 1), according to investigations into its role in cancer illustrated above.

The natural expression of ROR $\beta$ is exclusively restricted to neuronal tissues; therefore, activation of $\operatorname{ROR} \beta$ transcription is predominantly found in neuroblastoma cell lines (56), and literature on the role of ROR $\beta$ in cancer is not much. Nevertheless, primary uterine leiomyosarcoma showed high ROR $\beta$ expression (30), pharyngeal carcinoma cells and colorectal cancer cells showed modulated $\operatorname{ROR} \beta$ expression $(29,31)$, and $\operatorname{ROR} \beta$ was related to metastasis in a metastatic colorectal cancer cell model (28), which are summarized in Table 1. Based on the studies mentioned above, ROR $\beta$ shows features of a tumor suppressor (Figure 1), but the potential roles of ROR $\beta$ in various cancers related processes such as tumor proliferation and metastasis warrant further investigation.

\section{ROR $\boldsymbol{\gamma}$ in Various Cancers}

On the contrary, ROR $\gamma$ and its isoforms are extensively found in various kinds of malignancies. The diverse roles of ROR $\gamma$ in distinct cancers are specifically described below and summarized in Table 1 and Figure 1.

\section{Hematological Malignancies}

ROR $\gamma$ was found to function as an important element in lymphatic tumors (32), and mice deficient in ROR $\gamma$ were shown to have a high incidence of lymphoma metastasis and death within 4 months (57). Moreover, ROR $\gamma$ is frequently studied in tumor-infiltrating immune cells. ROR $\gamma$ mRNA expression in total lymphocytes was found unchanged between multiple myeloma and healthy controls $(58,59)$, but it was identified upregulation in peripheral blood monocyte cell (PBMC) from multiple myeloma comparing with healthy controls (60).

\section{Breast Cancer}

ROR $\gamma$ was found to be significantly overexpressed among infiltrating IL-17 $7^{+} \mathrm{T}$ cells, which drive immunosuppression in BC (61), and in breast tumor tissues compared with control tissues (62). An investigation related to group 3 innate lymphoid cells (ILC3) in BC revealed a role for ROR $\gamma \mathrm{t}+$ ILC3 in promoting lymph node metastasis by modulating chemokines in the tumor microenvironment (63). ROR $\gamma$ was found to be decreased in basal-like and grade 3 BCs, and inhibition of ROR $\gamma$ blocked cell viability, migration, and epithelial-mesenchymal transition (EMT) (64). However, an earlier study suggested that high expression of ROR $\gamma 1$, but not ROR $\gamma t$, by cancer cells was related to a high distance metastasis-free survival and was inversely correlated with decreased expression of PRMT2, which could suppress cell migration in $\mathrm{BC}$ (33). Accordingly, the different functions of ROR $\gamma$ in BC may be due to distinct cell origins and isotypes. For instance, when expressed by immune cells, ROR $\gamma$ acts as an immune suppressor, although when produced by cancer cells, it acts as a potential survival factor.

\section{Skin Cancer}

ROR $\gamma 1$ regulated tumor-promoting "emergency" granulomonocytopoiesis by suppressing negative (Socs3 and Bcl3) and promoting positive $(\mathrm{C} / \mathrm{EBPb})$ regulators of granulopoiesis and ROR $\gamma 1$ promoted expansion of tumor-promoting MDSCs and TAM in fibrocarcinoma mice models (65). In a study exploring the function of Th17 cells in antitumor immunity, ROR $\gamma \mathrm{t}$ was found to be expressed by tumor-infiltrating Th17 cells. Th17 cells did not exhibit in vitro tumor cell killing activity, although $\mathrm{CD}^{+}$ cytotoxic T cells stimulated by Th17 cells could activate the tumor killing response in a mouse B16 melanoma model (66).

In another study, ROR $\gamma$-deficient mice showed inhibited melanoma growth, and this effect was identified to be IL-9 dependent (67). Together with ROR $\alpha, \operatorname{ROR} \gamma$ was found to be expressed in melanoma cell lines and could bind with vitamin D3 derivatives, including 20(OH)D3 and 20,23(OH)2D3 (5), active forms of secosteroids and lumisterol can have anti-melanoma activity through action on $\operatorname{ROR} \alpha$ and $\operatorname{ROR} \gamma(22,24,25,39)$. In another study, ROR $\gamma$ and ROR $\alpha$ expression levels were decreased during melanoma progression, with the lowest expression levels in stages 


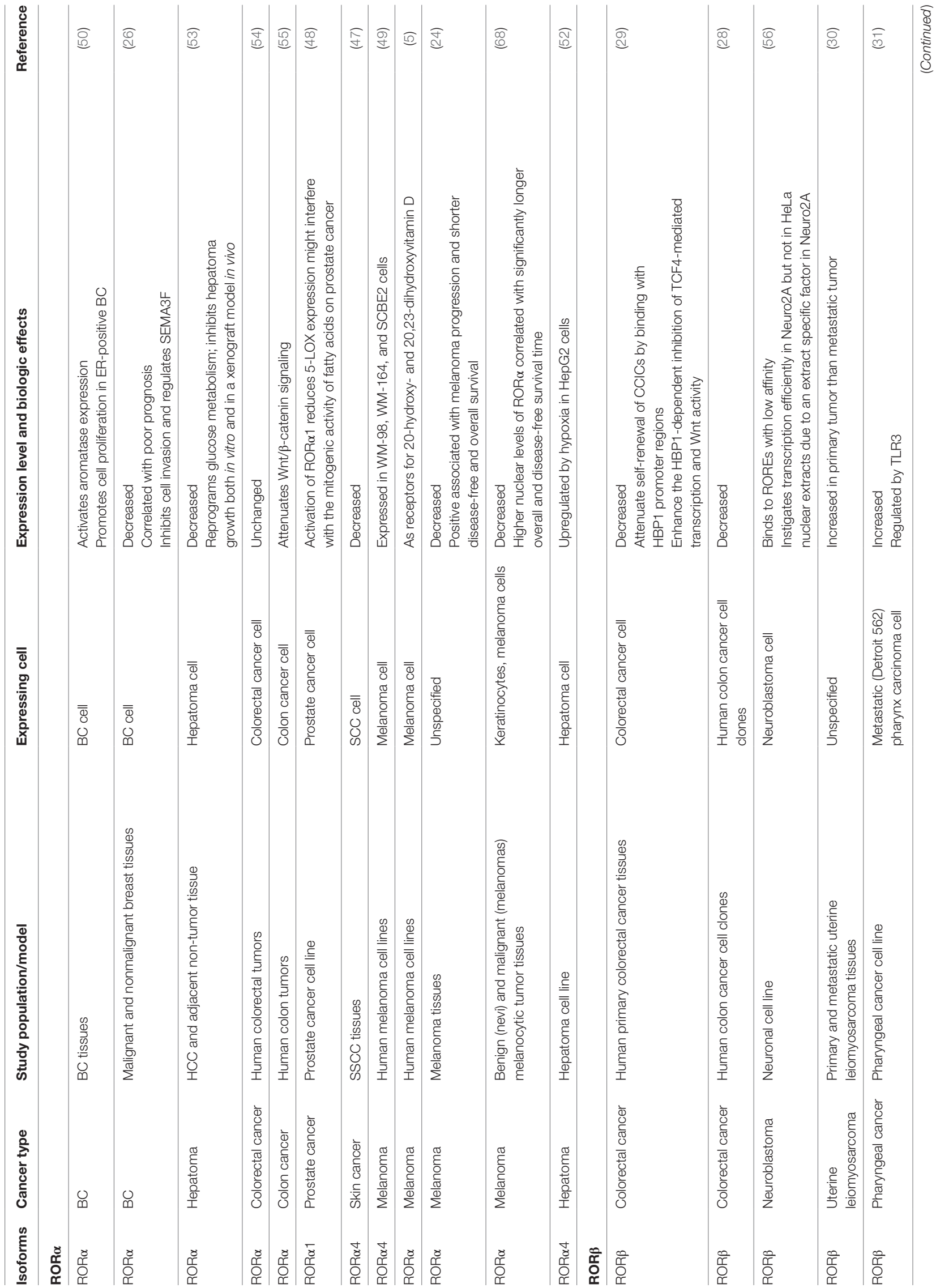




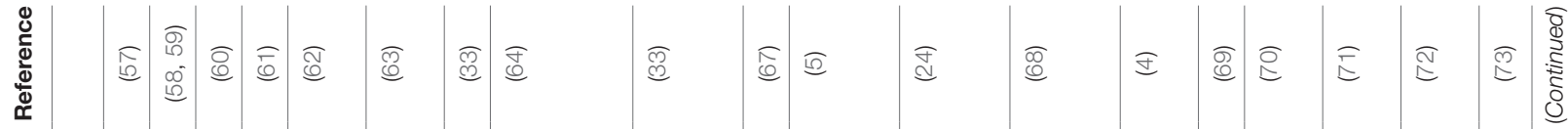
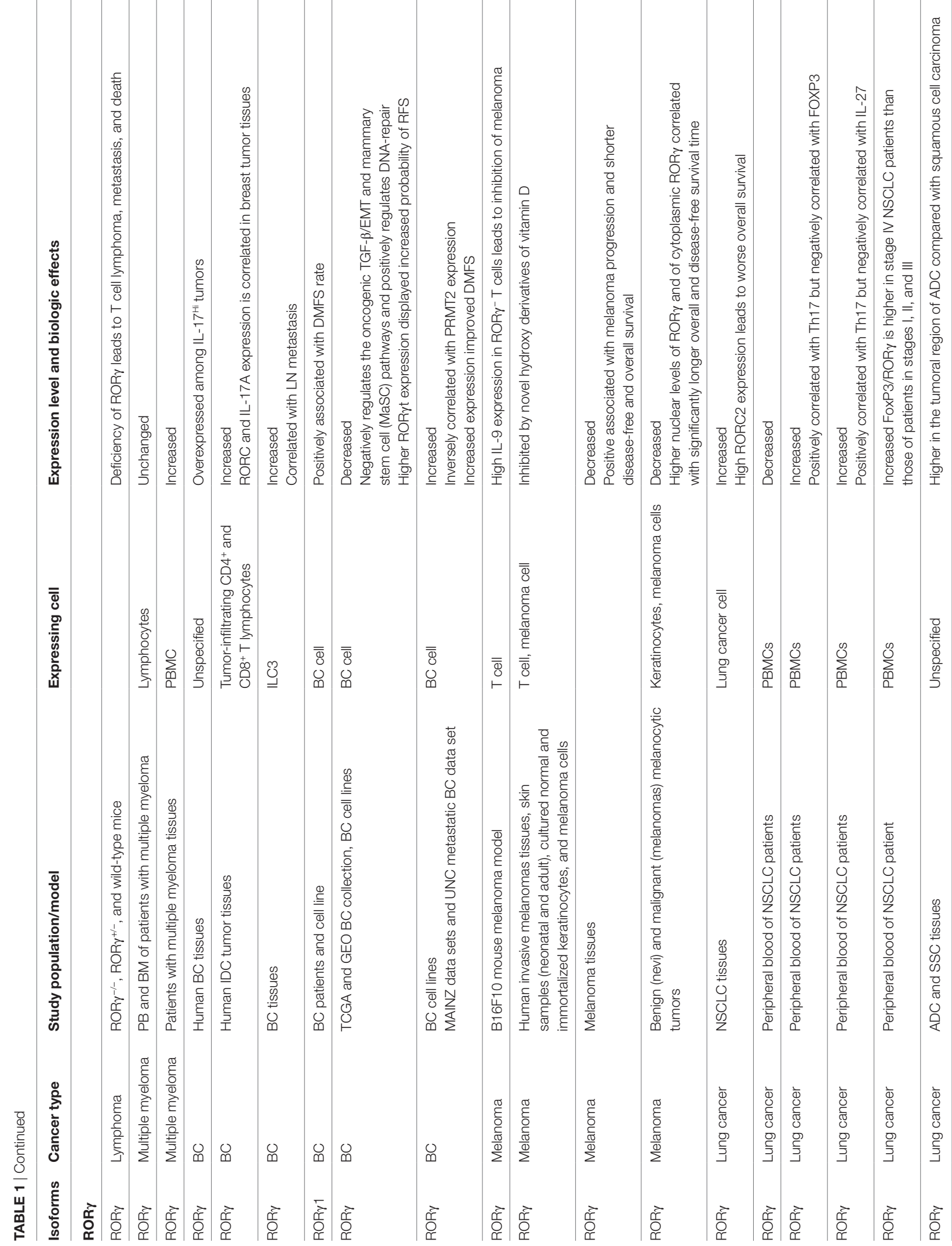


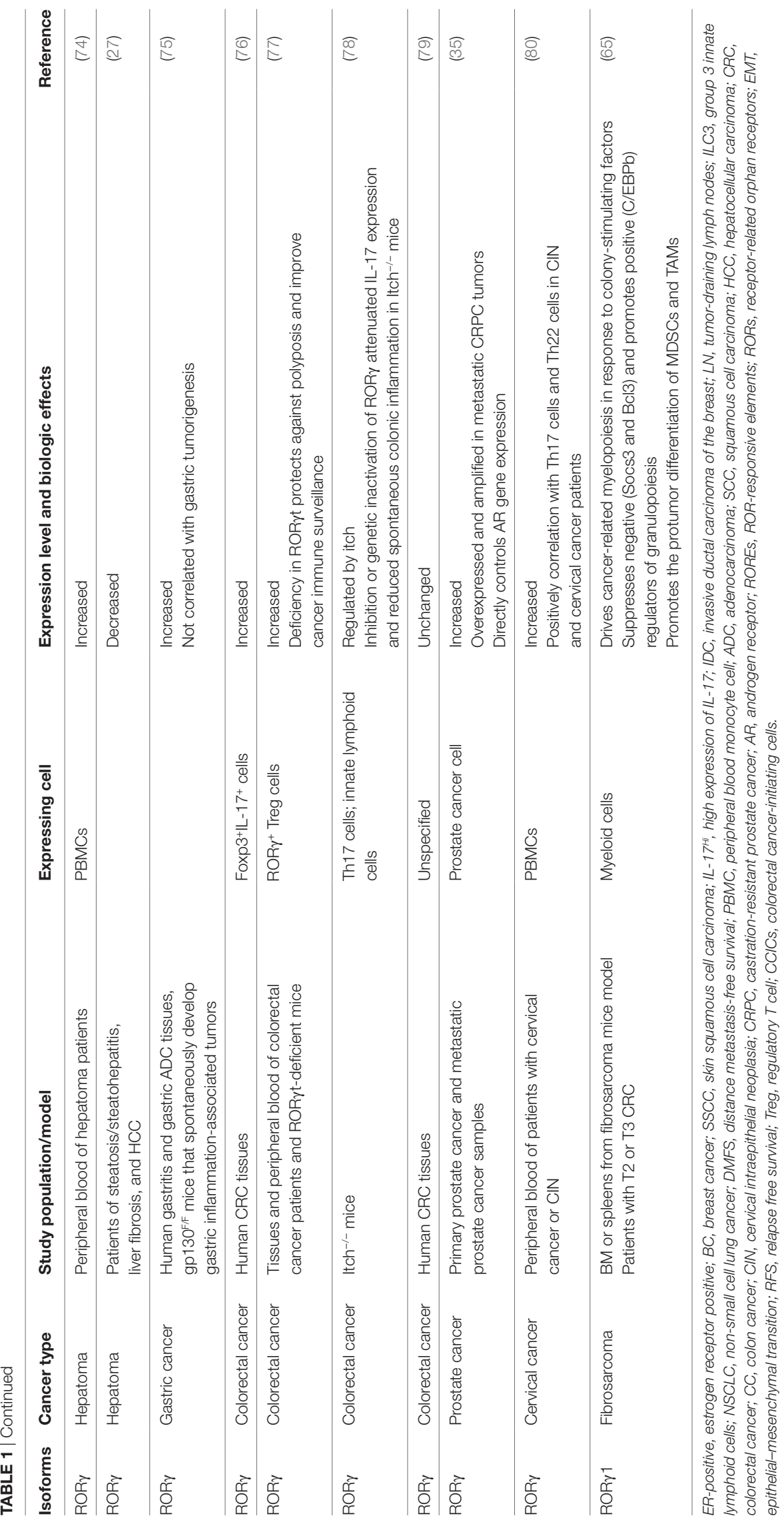




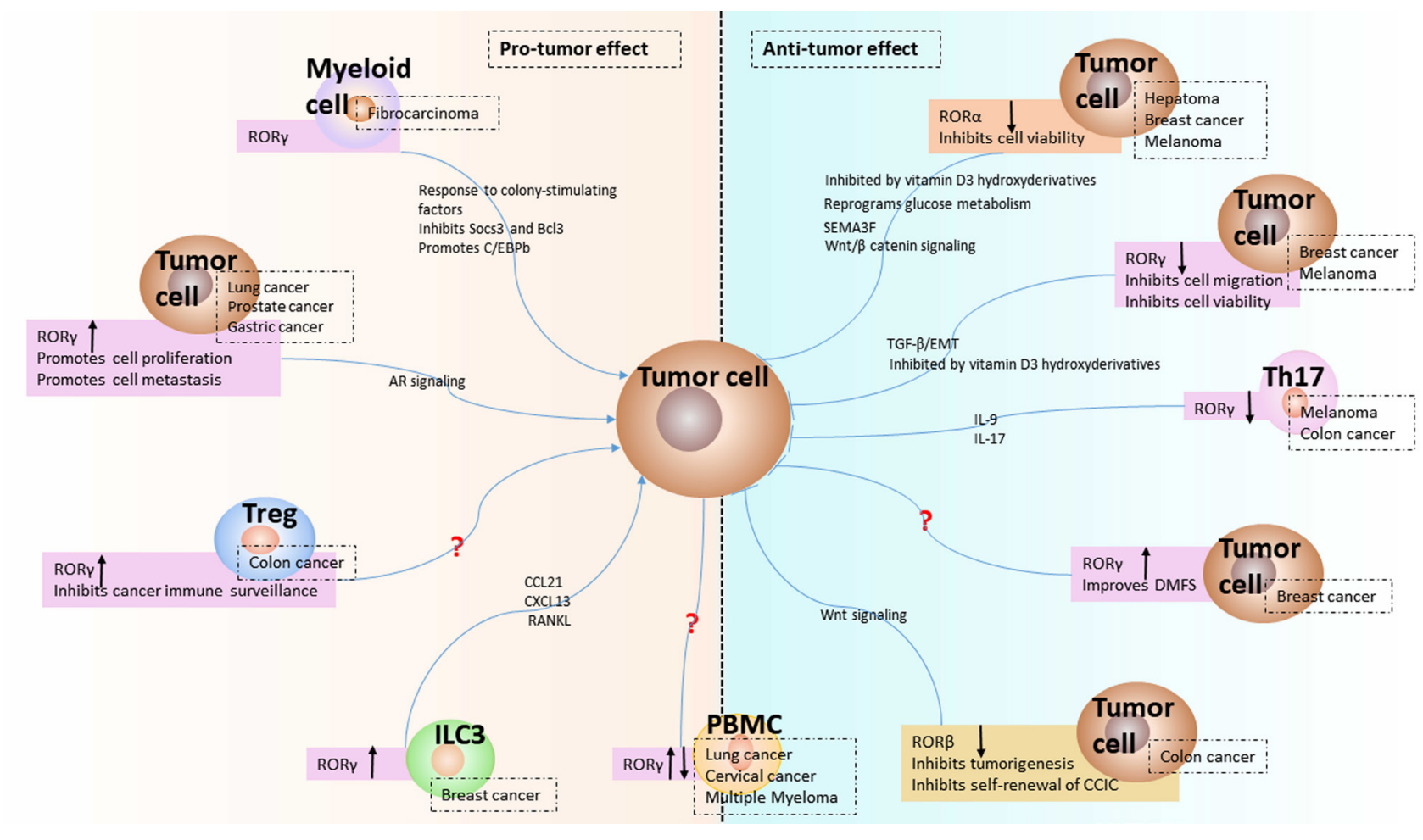

FIGURE 1 | Expression and function of receptor-related orphan receptors (RORs) in tumor microenvironment. The expression of ROR $\alpha$ and ROR $\beta$ from tumor cell and the modulated expression of RORy in group 3 innate lymphoid cells (ILC3), Th17, regulatory T cell (Treg), myeloid cell, and tumor cell from tumor microenvironment are presented as reviewed in the text. The downregulation of ROR $\alpha$ and ROR $\beta$ induce antitumor effect in hepatoma, breast cancer (BC), melanoma, and colon cancer. The upregulation of RORy in ILC3 leads to protumor effect by chemokines in BC. The downregulation of RORy in Th17 indicates antitumor effect by IL-17 in colon cancer. The upregulation of ROR $y$ in Treg shows protumor effect in colon cancer. The expression of ROR $\gamma$ in myeloid cell has protumor effects via Socs3, Bcl3, and C/EBPb. The expression of ROR $\gamma$ in tumor cell is either increased or decreased depending on the cancer type. Increased expression of ROR $\gamma$ in lung cancer, prostate cancer, and gastric cancer results in protumor effect, while decreased expression of RORy in BC and melanoma could induce antitumor effect via TGF $/$ /epithelial-mesenchymal transition (EMT) or vitamin D3 derivatives. The question mark refers to unknown mechanisms. The up or down black arrow refers to upregulation or downregulation. Antitumor: inhibits tumor progression; protumor: promotes tumor progression.

III and IV primary melanomas and in melanoma (68). These studies of ROR $\alpha$ and ROR $\gamma$ in melanoma suggest that ROR $\alpha$ and ROR $\gamma$ could be important modulators affecting melanomagenesis, contributing to the anti-melanoma activity of vitamin D3 and act as potential therapeutic targets in adjuvant melanoma therapy $(23,24)$. The investigation of ROR $\gamma$ in skin cancer seems to be concentrated on melanoma and the isotype ROR $\gamma 1$, thus, there is a need for further exploration focusing on the regulation of ROR $\gamma$ and its roles in other types of skin cancer.

\section{Lung Cancer}

Our previous study showed that ROR $\gamma 2$ was highly expressed in non-small cell lung cancer (NSCLC) cells and also served as a prognostic factor (4). The expression of ROR $\gamma \mathrm{t}$ mRNA and protein was found to be downregulated in PBMCs from NSCLC patients compared with controls (69). However, ROR $\gamma \mathrm{t}$ mRNA was found to be upregulated in the peripheral blood of patients with NSCLC compared with that of healthy controls (70), which was confirmed in other studies $(71,72)$. Moreover, in a recent report, ROR $\gamma$ t, together with Th17/IL-6R/pSTAT3/BATF, was upregulated in the tumor region of adenocarcinomas, except for squamous carcinomas of lung cancer (73). Studies focused on cancer cell-derived ROR $\gamma \mathrm{t}$ are infrequent and require additional attention.

\section{Hepatocellular Carcinoma}

ROR $\gamma \mathrm{t}$ mRNA was shown to be increased in HCC compared with a normal control group (74). By contrast, ROR $\gamma t$ mRNA expression was found to be significantly lower in patients with steatosis/ steatohepatitis, liver fibrosis, and HCC (27). Investigations into $\mathrm{ROR} \gamma \mathrm{t}$ in HCC are rare, although ROR $\gamma \mathrm{t}$ is known to be expressed in hepatocytes. There could be additional modulatory roles for ROR $\gamma \mathrm{t}$ in HCC progression, and further studies are warranted.

\section{Gastrointestinal Cancer}

The gene expression of IL-17A and ROR $\gamma$ was not altered in gastric cancer (75). Foxp $3^{+} \mathrm{IL}-17^{+}$cells in colorectal cancer were found to express ROR $\gamma \mathrm{t}$ (76). Another study described ROR $\gamma \mathrm{t}-$ expressing regulatory $\mathrm{T}$ cells that were linked with the inability of these cells to suppress inflammation and were directly associated with the stage of human colon cancer (77). ROR $\gamma t$ was also found to be involved in inhibiting colon carcinogenesis through binding with an E3 ubiquitin ligase, Itch, for ubiquitination (78). However, $\mathrm{ROR} \gamma \mathrm{t}$ was not expressed within colorectal cancer tissues or by 
colorectal cancer-infiltrating $\mathrm{CD}^{+}{ }^{+} \mathrm{T}$ cells (79). The expression and regulation of ROR $\gamma \mathrm{t}$ in gastric and colorectal cancer remain controversial, which makes it difficult to conclude the extent of $\mathrm{ROR} \gamma / \mathrm{ROR} \gamma \mathrm{t}$ expression or the involvement in tumorigenesis. However, the differences in results from different studies might be attributable to the diversity of detection methods from tissue samples when considering individual variation.

\section{Genitourinary Cancer}

In castration-resistant prostate cancer (CRPC), ROR $\gamma$ was examined as a therapeutic target due to its overexpression and was found to directly drive androgen receptor (AR) hyperactivity through binding to an exonic RORE and partly through the NR coactivators SRC-1 and -3 (35). Therefore, inhibition of ROR $\gamma$ may represent a possible treatment option for CRPC. The transcriptional expression of ROR $\gamma$ mRNA from PBMCs exhibited high levels in cervical cancer compared with healthy controls (80). Additional observations are needed to elucidate the functions of $\mathrm{ROR} \gamma$ in genitourinary cancer, where it may serve as a valuable therapeutic target.

\section{PERSPECTIVE}

The three ROR family members are regarded as important regulators of the circadian rhythm, metabolism, and tumorigenesis. As discussed in this review, the protumor or antitumor effects of ROR $\alpha$ and ROR $\beta$ in cancer have not been intensively explored, requiring further study and evidence. However, as the main transcription factor in IL-17-expressing immune cells, ROR $\gamma$ has been investigated in various cancer cells and tumor-infiltrating cells (Figure 1), indicating that it might be a promising prognostic factor in lung and $\mathrm{BC}$ and a potential therapeutic target in prostate cancer.

Moreover, according to this review, we could conclude that the roles that RORs family members play in tumorigenesis vary in different cancers and, to some extent, depend on producing cells in the tumor microenvironment. Further concentration on the relationships between RORs and tumorigenesis should be meticulously organized and should deeply explore the clinical significance and the underlying mechanisms. More importantly, each RORs family members consists of several isoforms, and some previous studies have showed that different RORs isoforms present different biological functions (6). Thus, prospective reports on therapeutic targets of RORs in cancer should identify all isoforms of specific RORs.

\section{REFERENCES}

1. Siegel RL, Miller KD, Jemal A. Cancer statistics, 2017. CA Cancer J Clin (2017) 67(1):7-30. doi:10.3322/caac.21387

2. Vacca M, Degirolamo C, Massafra V, Polimeno L, Mariani-Costantini R, Palasciano G, et al. Nuclear receptors in regenerating liver and hepato cellular carcinoma. Mol Cell Endocrinol (2013) 368(1-2):108-19. doi:10.1016/j. mce.2012.06.025

3. Li XB, Jiao S, Sun H, Xue J, Zhao WT, Fan L, et al. The orphan nuclear receptor EAR2 is overexpressed in colorectal cancer and it regulates survivability of colon cancer cells. Cancer Lett (2011) 309(2):137-44. doi:10.1016/j. canlet.2011.05.025

4. Huang Q, Fan J, Qian X, Lv Z, Zhang X, Han J, et al. Retinoic acid-related orphan receptor $\mathrm{C}$ isoform 2 expression and its prognostic significance for
Since ROR $\alpha$ and ROR $\gamma$ are dysregulated in multiple cancer types based on published articles, they likely participate in carcinogenesis through modulating molecules such as IL-17, PRMT2, and AR or as receptors for sterols, such as vitamin D3 derivatives. Intriguingly, IL-17, AR, and vitamin D3 are therapeutic targets in rheumatoid arthritis and have potential, as a frontline treatment option for advanced prostate cancer and an adjuvant in melanoma management. Agonists or inverse agonists for ROR $\alpha$ and ROR $\gamma$ might be efficiently inhibiting tumor growth and progression through activation or inactivation so that their ligands or targets, such as vitamin D3 derivatives and AR, become valid or invalid. Another promising new strategy for anticancer therapy might involve directly targeting tumor cells with ROR $\alpha$ - and ROR $\gamma$-specific modulators due to the correlations between high or low expression of ROR $\alpha$ and ROR $\gamma$ and tumor progression. Third, RORs are sometimes produced by immune cells in tumor microenvironments and then induce antitumor or protumor activity by regulating tumor-related cytokines or chemokines. Accordingly, therapies targeting RORs producing immune cells could be novel treatments for certain cancers.

\section{AUTHOR CONTRIBUTIONS}

JF, ZL and GY wrote the draft. YJ revised the manuscript. JF, TL, $\mathrm{JX}$, and FW designed the figures. QH, MG, GH, MZ, LD and SL commented and added extra information.

\section{FUNDING}

This paper was supported by the National Natural Science Foundation of China (no. 81572942, no. 81770096), Hubei province technical innovation special major project (2017ACA094), the Natural Science Foundation of Hubei Province (no. 2014CFA057), the Health and Planning Commission Fund of Hubei Province (WJ2017M098), the Science and Technology Support Program of Hubei Province (YSF2015001294), the Wuhan Planning Project of Science and Technology (no. 2014060101010036), the Special Fund for Industrial Transformation and Upgrading, the Independent Innovation Research Fund for Huazhong University of Science and Technology (no. 017KFYXJJ253), the Scientific Training Program for Young Talents from Union Hospital of Tongji Medical College, Huazhong University of Science and Technology (to JF), and the National major new drug discovery technology major special projects (2018ZX09301001001).

non-small cell lung cancer. J Cancer Res Clin Oncol (2016) 142(1):263-72. doi:10.1007/s00432-015-2040-0

5. Slominski AT, Kim TK, Takeda Y, Janjetovic Z, Brozyna AA, Skobowiat C, et al. RORalpha and ROR gamma are expressed in human skin and serve as receptors for endogenously produced noncalcemic 20-hydroxy- and 20,23-dihydroxyvitamin D. FASEB J (2014) 28(7):2775-89. doi:10.1096/fj.13-242040

6. Jetten AM, Takeda Y, Slominski A, Kang HS. Retinoic acid-related orphan receptor gamma (RORgamma): connecting sterol metabolism to regulation of the immune system and autoimmune disease. Curr Opin Toxicol (2018) 8:66-80. doi:10.1016/j.cotox.2018.01.005

7. Kojima H, Takeda Y, Muromoto R, Takahashi M, Hirao T, Takeuchi S, et al. Isoflavones enhance interleukin-17 gene expression via retinoic acid receptor-related orphan receptors alpha and gamma. Toxicology (2015) 329:32-9. doi:10.1016/j.tox.2015.01.007 
8. Solt LA, Kumar N, Nuhant P, Wang Y, Lauer JL, Liu J, et al. Suppression of TH17 differentiation and autoimmunity by a synthetic ROR ligand. Nature (2011) 472(7344):491-4. doi:10.1038/nature10075

9. Dong C. TH17 cells in development: an updated view of their molecular identity and genetic programming. Nat Rev Immunol (2008) 8(5):337-48. doi:10.1038/nri2295

10. Cua DJ, Tato CM. Innate IL-17-producing cells: the sentinels of the immune system. Nat Rev Immunol (2010) 10(7):479-89. doi:10.1038/nri2800

11. Guillaumond F, Dardente H, Giguere V, Cermakian N. Differential control of Bmall circadian transcription by REV-ERB and ROR nuclear receptors. J Biol Rhythms (2005) 20(5):391-403. doi:10.1177/0748730405277232

12. Akashi M, Takumi T. The orphan nuclear receptor RORalpha regulates circadian transcription of the mammalian core-clock Bmall. Nat Struct Mol Biol (2005) 12(5):441-8. doi:10.1038/nsmb925

13. Andre E, Conquet F, Steinmayr M, Stratton SC, Porciatti V, Becker-Andre M. Disruption of retinoid-related orphan receptor beta changes circadian behavior, causes retinal degeneration and leads to vacillans phenotype in mice. EMBOJ (1998) 17(14):3867-77. doi:10.1093/emboj/17.14.3867

14. Masana MI, Sumaya IC, Becker-Andre M, Dubocovich ML. Behavioral characterization and modulation of circadian rhythms by light and melatonin in $\mathrm{C} 3 \mathrm{H} /$ HeN mice homozygous for the RORbeta knockout. Am J Physiol Regul Integr Comp Physiol (2007) 292(6):R2357-67. doi:10.1152/ajpregu.00687.2006

15. Takeda Y, Jothi R, Birault V, Jetten AM. RORgamma directly regulates the circadian expression of clock genes and downstream targets in vivo. Nucleic Acids Res (2012) 40(17):8519-35. doi:10.1093/nar/gks630

16. Takeda Y, Kang HS, Angers M, Jetten AM. Retinoic acid-related orphan receptor gamma directly regulates neuronal PAS domain protein 2 transcription in vivo. Nucleic Acids Res (2011) 39(11):4769-82. doi:10.1093/nar/ gkq1335

17. Jetten AM, Kang HS, Takeda Y. Retinoic acid-related orphan receptors alpha and gamma: key regulators of lipid/glucose metabolism, inflammation, and insulin sensitivity. Front Endocrinol (2013) 4:1. doi:10.3389/fendo.2013.00001

18. Kim K, Boo K, Yu YS, Oh SK, Kim H, Jeon Y, et al. RORalpha controls hepatic lipid homeostasis via negative regulation of PPARgamma transcriptional network. Nat Commun (2017) 8(1):162. doi:10.1038/s41467-017-00215-1

19. Shajari S, Laliena A, Heegsma J, Tunon MJ, Moshage H, Faber KN. Melatonin suppresses activation of hepatic stellate cells through RORalpha-mediated inhibition of 5-lipoxygenase. J Pineal Res (2015) 59(3):391-401. doi:10.1111/ jpi. 12271

20. Zhao Y, Xu L, Ding S, Lin N, Ji Q, Gao L, et al. Novel protective role of the circadian nuclear receptor retinoic acid-related orphan receptor-alpha in diabetic cardiomyopathy. J Pineal Res (2017) 62(3):e12378. doi:10.1111/jpi.12378

21. Slominski A, Fischer TW, Zmijewski MA, Wortsman J, Semak I, Zbytek B, et al. On the role of melatonin in skin physiology and pathology. Endocrine (2005) 27(2):137-48. doi:10.1385/ENDO:27:2:137

22. Slominski AT, Kim TK, Hobrath JV, Oak ASW, Tang EKY, Tieu EW, et al. Endogenously produced nonclassical vitamin D hydroxy-metabolites act as "biased" agonists on VDR and inverse agonists on RORalpha and RORgamma. J Steroid Biochem Mol Biol (2017) 173:42-56. doi:10.1016/j.jsbmb.2016.09.024

23. Brozyna AA, Jozwicki W, Roszkowski K, Filipiak J, Slominski AT. Melanin content in melanoma metastases affects the outcome of radiotherapy. Oncotarget (2016) 7(14):17844-53. doi:10.18632/oncotarget.7528

24. Slominski AT, Brozyna AA, Skobowiat C, Zmijewski MA, Kim TK, Janjetovic Z, et al. On the role of classical and novel forms of vitamin D in melanoma progression and management. J Steroid Biochem Mol Biol (2018) 177:159-70. doi:10.1016/j.jsbmb.2017.06.013

25. Slominski AT, Brozyna AA, Zmijewski MA, Jozwicki W, Jetten AM, Mason RS, et al. Vitamin D signaling and melanoma: role of vitamin D and its receptors in melanoma progression and management. Lab Invest (2017) 97(6):706-24. doi:10.1038/labinvest.2017.3

26. Xiong G, Wang C, Evers BM, Zhou BP, Xu R. RORalpha suppresses breast tumor invasion by inducing SEMA3F expression. Cancer Res (2012) 72(7): 1728-39. doi:10.1158/0008-5472.CAN-11-2762

27. Ou Z, Shi X, Gilroy RK, Kirisci L, Romkes M, Lynch C, et al. Regulation of the human hydroxysteroid sulfotransferase (SULT2A1) by RORalpha and RORgamma and its potential relevance to human liver diseases. Mol Endocrinol (2013) 27(1):106-15. doi:10.1210/me.2012-1145

28. Chen Q, Chen L, Zhao R, Yang XD, Imran K, Xing CG. Microarray analyses reveal liver metastasis-related genes in metastatic colorectal cancer cell model. J Cancer Res Clin Oncol (2013) 139(7):1169-78. doi:10.1007/s00432013-1424-2

29. Wen Z, Pan T, Yang S, Liu J, Tao H, Zhao Y, et al. Up-regulated NRIP2 in colorectal cancer initiating cells modulates the Wnt pathway by targeting RORbeta. Mol Cancer (2017) 16(1):20. doi:10.1186/s12943-017-0590-2

30. Davidson B, Abeler VM, Forsund M, Holth A, Yang Y, Kobayashi Y, et al. Gene expression signatures of primary and metastatic uterine leiomyosarcoma. Hum Pathol (2014) 45(4):691-700. doi:10.1016/j.humpath.2013.11.003

31. Matijevic T, Pavelic J. The dual role of TLR3 in metastatic cell line. Clin Exp Metastasis (2011) 28(7):701-12. doi:10.1007/s10585-011-9402-Z

32. Liljevald M, Rehnberg M, Soderberg M, Ramnegard M, Borjesson J, Luciani D, et al. Retinoid-related orphan receptor gamma (RORgamma) adult induced knockout mice develop lymphoblastic lymphoma. Autoimmun Rev (2016) 15(11):1062-70. doi:10.1016/j.autrev.2016.07.036

33. Oh TG, Bailey P, Dray E, Smith AG, Goode J, Eriksson N, et al. PRMT2 and RORgamma expression are associated with breast cancer survival outcomes. Mol Endocrinol (2014) 28(7):1166-85. doi:10.1210/me.2013-1403

34. Hu X, Liu X, Moisan J, Wang Y, Lesch CA, Spooner C, et al. Synthetic RORgamma agonists regulate multiple pathways to enhance antitumor immunity. Oncoimmunology (2016) 5(12):e1254854. doi:10.1080/2162402X.2016. 1254854

35. Wang J, Zou JX, Xue X, Cai D, Zhang Y, Duan Z, et al. Corrigendum: RORgamma drives androgen receptor expression and represents a therapeutic target in castration-resistant prostate cancer. Nat Med (2016) 22(6):692. doi:10.1038/nm0616-692b

36. Solt LA, Griffin PR, Burris TP. Ligand regulation of retinoic acid receptorrelated orphan receptors: implications for development of novel therapeutics. Curr Opin Lipidol (2010) 21(3):204-11. doi:10.1097/MOL.0b013e328338ca18

37. Kallen J, Schlaeppi JM, Bitsch F, Delhon I, Fournier B. Crystal structure of the human RORalpha ligand binding domain in complex with cholesterol sulfate at 2.2 A. J Biol Chem (2004) 279(14):14033-8. doi:10.1074/jbc.M400302200

38. Stehlin-Gaon C, Willmann D, Zeyer D, Sanglier S, Van Dorsselaer A, Renaud JP, et al. All-trans retinoic acid is a ligand for the orphan nuclear receptor ROR beta. Nat Struct Biol (2003) 10(10):820-5. doi:10.1038/ nsb979

39. Slominski AT, Kim TK, Hobrath JV, Janjetovic Z, Oak ASW, Postlethwaite A, et al. Characterization of a new pathway that activates lumisterol in vivo to biologically active hydroxylumisterols. Sci Rep (2017) 7(1):11434. doi:10.1038/ s41598-017-10202-7

40. Wiesenberg I, Missbach M, Kahlen JP, Schrader M, Carlberg C. Transcriptional activation of the nuclear receptor RZR alpha by the pineal gland hormone melatonin and identification of CGP 52608 as a synthetic ligand. Nucleic Acids Res (1995) 23(3):327-33. doi:10.1093/nar/23.3.327

41. Lardone PJ, Guerrero JM, Fernandez-Santos JM, Rubio A, Martin-Lacave I, Carrillo-Vico A. Melatonin synthesized by $\mathrm{T}$ lymphocytes as a ligand of the retinoic acid-related orphan receptor. J Pineal Res (2011) 51(4):454-62. doi:10.1111/j.1600-079X.2011.00909.x

42. Slominski AT, Zmijewski MA, Jetten AM. RORalpha is not a receptor for melatonin (response to DOI 10.1002/bies.201600018). Bioessays (2016) 38(12): 1193-4. doi:10.1002/bies.201600204

43. Ram PT, Dai J, Yuan L, Dong C, Kiefer TL, Lai L, et al. Involvement of the mt 1 melatonin receptor in human breast cancer. Cancer Lett (2002) 179(2):141-50. doi:10.1016/S0304-3835(01)00873-4

44. Kojetin DJ, Burris TP. REV-ERB and ROR nuclear receptors as drug targets. Nat Rev Drug Discov (2014) 13(3):197-216. doi:10.1038/nrd4100

45. Chang MR, Lyda B, Kamenecka TM, Griffin PR. Pharmacologic repression of retinoic acid receptor-related orphan nuclear receptor gamma is therapeutic in the collagen-induced arthritis experimental model. Arthritis Rheumatol (2014) 66(3):579-88. doi:10.1002/art.38272

46. Wang Y, Solt LA, Kojetin DJ, Burris TP. Regulation of p53 stability and apoptosis by a ROR agonist. PLoS One (2012) 7(4):e34921. doi:10.1371/journal. pone.0034921

47. Dai J, Brooks Y, Lefort K, Getsios S, Dotto GP. The retinoid-related orphan receptor ROR $\alpha$ promotes keratinocyte differentiation via FOXN1. PLoS One (2013) 8(7):e70392. doi:10.1371/journal.pone.0070392

48. Moretti RM, Montagnani Marelli M, Sala A, Motta M, Limonta P. Activation of the orphan nuclear receptor RORalpha counteracts the proliferative effect of fatty acids on prostate cancer cells: crucial role of 5-lipoxygenase. Int J Cancer (2004) 112(1):87-93. doi:10.1002/ijc.20387 
49. Fischer TW, Zmijewski MA, Zbytek B, Sweatman TW, Slominski RM, Wortsman J, et al. Oncostatic effects of the indole melatonin and expression of its cytosolic and nuclear receptors in cultured human melanoma cell lines. Int J Oncol (2006) 29(3):665-72. doi:10.3892/ijo.29.3.665

50. Odawara H, Iwasaki T, Horiguchi J, Rokutanda N, Hirooka K, Miyazaki W, et al. Activation of aromatase expression by retinoic acid receptor-related orphan receptor (ROR) alpha in breast cancer cells: identification of a novel ROR response element. J Biol Chem (2009) 284(26):17711-9. doi:10.1074/jbc. M109.009241

51. Du J, Xu R. RORalpha, a potential tumor suppressor and therapeutic target of breast cancer. Int J Mol Sci (2012) 13(12):15755-66. doi:10.3390/ ijms131215755

52. Chauvet C, Bois-Joyeux B, Danan JL. Retinoic acid receptor-related orphan receptor (ROR) alpha4 is the predominant isoform of the nuclear receptor RORalpha in the liver and is up-regulated by hypoxia in HepG2 human hepatoma cells. Biochem J (2002) 364(Pt 2):449-56. doi:10.1042/bj20011558

53. Byun JK, Choi YK, Kang YN, Jang BK, Kang KJ, Jeon YH, et al. Retinoic acid-related orphan receptor alpha reprograms glucose metabolism in glutamine-deficient hepatoma cells. Hepatology (2015) 61(3):953-64. doi:10.1002/hep. 27577

54. Leon J, Casado J, Carazo A, Sanjuan L, Mate A, Munoz de Rueda P, et al. Gender-related invasion differences associated with mRNA expression levels of melatonin membrane receptors in colorectal cancer. Mol Carcinog (2012) 51(8):608-18. doi:10.1002/mc.20832

55. Lee JM, Kim IS, Kim H, Lee JS, Kim K, Yim HY, et al. RORalpha attenuates Wnt/beta-catenin signaling by PKCalpha-dependent phosphorylation in colon cancer. Mol Cell (2010) 37(2):183-95. doi:10.1016/j.molcel.2009.12.022

56. Gawlas K, Stunnenberg HG. Differential transcription of the orphan receptor RORbeta in nuclear extracts derived from Neuro2A and HeLa cells. Nucleic Acids Res (2001) 29(16):3424-32. doi:10.1093/nar/29.16.3424

57. Ueda E, Kurebayashi S, Sakaue M, Backlund M, Koller B, Jetten AM. High incidence of T-cell lymphomas in mice deficient in the retinoid-related orphan receptor RORgamma. Cancer Res (2002) 62(3):901-9.

58. Wang M, Chen P, Jia Y, He N, Li D, Ji C, et al. Elevated Th22 as well as Th17 cells associated with therapeutic outcome and clinical stage are potential targets in patients with multiple myeloma. Oncotarget (2015) 6(20):17958-67. doi:10.18632/oncotarget.4641

59. Braga WM, da Silva BR, de Carvalho AC, Maekawa YH, Bortoluzzo AB, Rizzatti EG, et al. FOXP3 and CTLA4 overexpression in multiple myeloma bone marrow as a sign of accumulation of CD4(+) T regulatory cells. Cancer Immunol Immunother (2014) 63(11):1189-97.doi:10.1007/s00262-014-1589-9

60. Feng P, Yan R, Dai X, Xie X, Wen H, Yang S. The alteration and clinical significance of Th1/Th2/Th17/Treg cells in patients with multiple myeloma. Inflammation (2015) 38(2):705-9. doi:10.1007/s10753-014-9980-4

61. Thibaudin M, Chaix M, Boidot R, Vegran F, Derangere V, Limagne E, et al. Human ectonucleotidase-expressing CD25(high) Th17 cells accumulate in breast cancer tumors and exert immunosuppressive functions. Oncoimmunology (2016) 5(1):e1055444. doi:10.1080/2162402X.2015.1055444

62. Benevides L, Cardoso CR, Tiezzi DG, Marana HR, Andrade JM, Silva JS. Enrichment of regulatory $\mathrm{T}$ cells in invasive breast tumor correlates with the upregulation of IL-17A expression and invasiveness of the tumor. Eur J Immunol (2013) 43(6):1518-28. doi:10.1002/eji.201242951

63. Irshad S, Flores-Borja F, Lawler K, Monypenny J, Evans R, Male V, et al. RORgammat(+) innate lymphoid cells promote lymph node metastasis of breast cancers. Cancer Res (2017) 77(5):1083-96. doi:10.1158/0008-5472.CAN16-0598

64. Oh TG, Wang SM, Acharya BR, Goode JM, Graham JD, Clarke CL, et al. The nuclear receptor, RORgamma, regulates pathways necessary for breast cancer metastasis. EBioMedicine (2016) 6:59-72. doi:10.1016/j.ebiom.2016. 02.028

65. Strauss L, Sangaletti S, Consonni FM, Szebeni G, Morlacchi S, Totaro MG, et al. RORC1 regulates tumor-promoting "emergency" granulo-monocytopoiesis. Cancer Cell (2015) 28(2):253-69. doi:10.1016/j.ccell.2015.07.006
66. Ankathatti Munegowda M, Deng Y, Mulligan SJ, Xiang J. Th17 and Th17stimulated CD8(+) T cells play a distinct role in Th17-induced preventive and therapeutic antitumor immunity. Cancer Immunol Immunother (2011) 60(10):1473-84. doi:10.1007/s00262-011-1054-y

67. Purwar R, Schlapbach C, Xiao S, Kang HS, Elyaman W, Jiang X, et al. Robust tumor immunity to melanoma mediated by interleukin-9-producing $\mathrm{T}$ cells. Nat Med (2012) 18(8):1248-53. doi:10.1038/nm.2856

68. Brozyna AA, Jozwicki W, Skobowiat C, Jetten A, Slominski AT. RORalpha and RORgamma expression inversely correlates with human melanoma progression. Oncotarget (2016) 7(39):63261-82. doi:10.18632/oncotarget.11211

69. Zhao L, Yang J, Wang HP, Liu RY. Imbalance in the Th17/Treg and cytokine environment in peripheral blood of patients with adenocarcinoma and squamous cell carcinoma. Med Oncol (2013) 30(1):461. doi:10.1007/ s12032-013-0461-7

70. Duan MC, Han W, Jin PW, Wei YP, Wei Q, Zhang LM, et al. Disturbed Th17/Treg balance in patients with non-small cell lung cancer. Inflammation (2015) 38(6):2156-65. doi:10.1007/s10753-015-0198-x

71. Duan M, Ning Z, Fu Z, Zhang J, Liu G, Wei Q, et al. Decreased IL-27 negatively correlated with Th17 cells in non-small-cell lung cancer patients. Mediators Inflamm (2015) 2015:802939. doi:10.1155/2015/802939

72. Li S, Li Y, Qu X, Liu X, Liang J. Detection and significance of TregFoxP3(+) and Th17 cells in peripheral blood of non-small cell lung cancer patients. Arch Med Sci (2014) 10(2):232-9. doi:10.5114/aoms.2014.42573

73. Balabko L, Andreev K, Burmann N, Schubert M, Mathews M, Trufa DI, et al. Increased expression of the Th17-IL-6R/pSTAT3/BATF/RorgammaT-axis in the tumoural region of adenocarcinoma as compared to squamous cell carcinoma of the lung. Sci Rep (2014) 4:7396. doi:10.1038/srep07396

74. Lin ZW, Wu LX, Xie Y, Ou X, Tian PK, Liu XP, et al. The expression levels of transcription factors T-bet, GATA-3, RORgammat and FOXP3 in peripheral blood lymphocyte (PBL) of patients with liver cancer and their significance. Int J Med Sci (2015) 12(1):7-16. doi:10.7150/ijms.8352

75. Kennedy CL, Najdovska M, Jones GW, McLeod L, Hughes NR, Allison C, et al. The molecular pathogenesis of STAT3-driven gastric tumourigenesis in mice is independent of IL-17. J Pathol (2011) 225(2):255-64. doi:10.1002/path.2933

76. Yang S, Wang B, Guan C, Wu B, Cai C, Wang M, et al. Foxp3+IL-17+ T cells promote development of cancer-initiating cells in colorectal cancer. J Leukoc Biol (2011) 89(1):85-91. doi:10.1189/jlb.0910506

77. Blatner NR, Mulcahy MF, Dennis KL, Scholtens D, Bentrem DJ, Phillips JD, et al. Expression of RORgammat marks a pathogenic regulatory $\mathrm{T}$ cell subset in human colon cancer. Sci Transl Med (2012) 4(164):164ra59. doi:10.1126/ scitranslmed.3004566

78. Kathania M, Khare P, Zeng M, Cantarel B, Zhang H, Ueno H. Itch inhibits IL-17-mediated colon inflammation and tumorigenesis by ROR-gammat ubiquitination. Nat Immunol (2016) 17(8):997-1004. doi:10.1038/ni.3488

79. Punkenburg E, Vogler T, Buttner M, Amann K, Waldner M, Atreya R, et al. Batf-dependent Th17 cells critically regulate IL-23 driven colitis-associated colon cancer. Gut (2016) 65(7):1139-50. doi:10.1136/gutjnl-2014-308227

80. Zhang W, Tian X, Mumtahana F, Jiao J, Zhang T, Croce KD, et al. The existence of Th22, pure Th17 and Th1 cells in CIN and cervical cancer along with their frequency variation in different stages of cervical cancer. BMC Cancer (2015) 15:717. doi:10.1186/s12885-015-1767-y

Conflict of Interest Statement: The authors declare that the research was conducted in the absence of any commercial or financial relationships that could be construed as a potential conflict of interest.

Copyright (C) 2018 Fan, Lv, Yang, Liao, Xu, Wu, Huang, Guo, Hu, Zhou, Duan, Liu and Jin. This is an open-access article distributed under the terms of the Creative Commons Attribution License (CC BY). The use, distribution or reproduction in other forums is permitted, provided the original author(s) and the copyright owner are credited and that the original publication in this journal is cited, in accordance with accepted academic practice. No use, distribution or reproduction is permitted which does not comply with these terms. 